\title{
Baseline data of the presence of meso and microplastics in the digestive tract of a commercially important teleost fish from Río de la Plata Estuary System (Southwest Atlantic Ocean)
}

\author{
M. Agustina Mandiola ${ }^{1,}{ }^{*}$, Ramiro Bagnato ${ }^{2}$, Joaquín C. M. Gana ${ }^{1}$, M. Carolina De León ${ }^{1}$, \\ Mariela Dassis ${ }^{1}$, Diego Albareda ${ }^{3}$ and Pablo Denuncio ${ }^{1,4}$ \\ ${ }^{1}$ Instituto de Investigaciones Marinas y Costeras (IIMyC), Universidad Nacional de Mar del Plata (UNMdP), Consejo Nacional de \\ Investigaciones Científicas y Técnicas (CONICET), C. C. 1260, B7602HSA - Mar del Plata, Argentina. ${ }^{2}$ Freelance researcher. ${ }^{3}$ Departamento \\ de Conservación, Ecoparque, Ciudad Autónoma de Buenos Aires, Argentina. ${ }^{4}$ Asociación Naturalistas Geselinos, Villa Gesell, Argentina. \\ ORCID M. Agustina Mandiola (D) https://orcid.org/0000-0002-0746-8816, Joaquin C. M. Gana (D) https://orcid.org/0000-0002-3442-8879, \\ Mariela Dassis (D) https://orcid.org/0000-0002-1602-773X, Pablo Denuncio (D) https://orcid.org/0000-0002-6357-4082
}

Marine and Fishery Sciences MAFIS

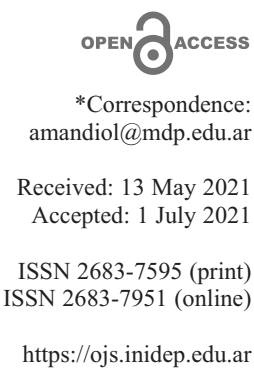

Journal of the Instituto Nacional de Investigación y Desarrollo Pesquero (INIDEP)

\section{This work is licensed under a Creative Commons Attribution- NonCommercial-ShareAlike 4.0} International License

\begin{abstract}
White croaker (Micropogonias furnieri) is the most important commercial fish of Río de la Plata Estuary System (RLPES), one of the most extensive on the western South Atlantic coast. This paper describes the occurrence, abundance, and type of plastic debris (PD) present on the digestive tracts of 65 white croakers in the RLPES. Eighty percent of analyzed individuals had ingested $\mathrm{PD}, 156$ of which $(\mathrm{FO}=83.9 \%$ ) were thread-like plastics and 30 were fragments $(\mathrm{FO}=16.1 \%)$. The average number of pieces per digestive tract was $2.83 \pm 3.14$. Microplastic represented $85 \%$ of $\mathrm{PD}$, most of them were $<2 \mathrm{~mm}$ and the prominent color was blue. Our results demonstrate the high occurrence of meso and microplastics in one of the most important species from an ecological and commercial viewpoint in the RLPES. The RLPES is the area of the Southwest Atlantic Ocean that concentrates most of the records of plastic waste in the environment, where the white croaker is the main commercial fish. In addition, M. furnieri is a main prey for several predators in the area. Although preliminary, this is a relevant contribution to the knowledge of marine debris pollution and its impact on the marine community of the region.
\end{abstract}

Key words: Marine debris ingestion, plastic pollution, Micropogonias furnieri, estuary, South America.

Primeros registros de la presencia de meso y microplásticos en el tracto digestivo de un importante pez comercial del Sistema del Estuario del Río de la Plata (Océano Atlántico Sudoccidental)

RESUMEN. La corvina rubia (Micropogonias furnieri) es el pez comercial más importante del Sistema del Estuario del Río de la Plata (RLPES), uno de los más extensos en la costa atlántica sudoccidental. En este trabajo se describe la ocurrencia, abundancia y tipo de desechos plásticos (DP) presentes en el tracto digestivo de 65 ejemplares de corvina rubia del RLPES. El 80\% de los individuos analizados había ingerido DP, de los cuales 156 eran plásticos filiformes $(\mathrm{FO}=83,9 \%)$ y 30 eran fragmentos $(\mathrm{FO}=16,1 \%)$. El número medio de piezas por tracto digestivo fue de 2,83 $\pm 3,14$. El microplástico representó el $85 \%$ de los DP, la mayoría de las cuales eran $<2 \mathrm{~mm}$ y el color predominante fue el azul. Nuestros resultados demuestran la alta ocurrencia de meso y microplásticos en una de las especies más importantes desde el punto de vista ecológico y comercial en el RLPES. El RLPES es el área del Océano Atlántico Sudoccidental que concentra la mayor parte de los registros de desechos plásticos en el medio ambiente, donde la corvina rubia es el principal pez comercial. 
Además, M. furnieri constituye una presa principal de varios depredadores de la zona. Aunque preliminar, esta es una contribución relevante al conocimiento de la contaminación por desechos marinos y su impacto en los organismos del Océano Atlántico Sudoccidental, particularmente en el RLPES.

Palabras clave: Ingestión de basura, plásticos marinos, Micropogonias furnieri, estuario, América del Sur.

Nowadays, there is growing global concern about pollution by plastic debris (PD), and marine ecosystems are particularly involved in this problem, being the final destination of most marine debris (Eriksen et al. 2014). An estimated 6-12 million tons of plastic enter the oceans each year (Jambeck et al. 2015), these circumstances are persistent in the environment and have negative impacts on marine fauna (Gregory 2009).

Entanglement and ingestion are the two main types of interaction by aquatic organisms (Laist 1997; Gall and Thompson 2015; Kühn and van Franeker 2020). The former is the most visible effect of PD on organisms and is mainly associated with suffocation and general debilitation (Gregory 2009; Jepsen and de Bruyn 2019), whereas the latter is less visible and recorded, and is related to satiation (Derraik 2002; Machovsky-Capuska et al. 2019; Santos et al. 2020). In fact, at least 750 marine species interact with PD (Gall and Thompson 2015). Records of PD ingestion on some marine species of commercial importance for human consumption have significantly increased over the last years throughout the world (Foekema et al. 2013; Lusher et al. 2013; Van Cauwenberghe and Janssen 2014; Devriese et al. 2015; Neves et al. 2015; Rochman 2015; Liboiron et al. 2016; Bessa et al. 2018; Ory et al. 2018; Arias et al. 2019; Azevedo-Santos et al. 2019). However, there is a lack of evidence of plastic transfer from seafood to humans (Akhbarizadeh et al. 2019).

In Argentina, fishing represents one of the most important economic activities for the country; in fact, more than $450,000 \mathrm{t}$ corresponding to 57 species of fish were caught in 2020 (MAGyP 2021). Nowadays, records of plastic ingestion in Argentine commercial fishes are very few, namely in silverside (Odontesthes bonariensis) from Río de la Plata Estuary System (RLPES) (Pazos et al. 2017) and white croaker (Micropogonia furnieri) from Bahía Blanca Estuary (Arias et al. 2019).

Estuaries and coastal areas of heavily anthropogenic impacted regions are the most polluted ecosystems with plastic debris (Eriksen et al. 2014; Galgani et al. 2015; Frère et al. 2017). In Argentina, the RLPES is an extensive and shallow coastal plain estuary on the western South Atlantic coast $\left(35^{\circ} \mathrm{S}-36^{\circ} \mathrm{S}\right)$ (Mianzan et al. 2001). The presence of more than 5 million inhabitants on its coasts (Baigún et al. 2016), added to oceanographic characteristics of the area, makes the estuary an area with high concentration of PD (Acha et al. 2003). In particular, the presence of PD has been found on different species, ranging from freshwater fishes to marine turtles, marine birds and marine mammals (Denuncio et al. 2011, 2017; Gonzalez Carman et al. 2014; Lenzi et al. 2016; Pazos et al. 2017; Burgues et al. 2020).

This area is also a highly productive system, where industrial and artisanal fisheries are very valuable, being $M$. furnieri one of the main species from the ecological (Denuncio et al. 2017; Franco Trecu et al. 2017) and commercial (Mianzan et al. 2001) viewpoints of the area. Due to the high concentration of PD found in the RLPES, this study is meant to assess the occurrence, abundance, and type of PD present on the digestive tract of this species.

Fish samples were purchased from a bottom trawling fishery company operating on the coastal area of Bahía San Borombón (RLPES, $36^{\circ} 26^{\prime} \mathrm{S}-57^{\circ} 70^{\prime} \mathrm{W}$ ) in August 2017 (Figure 1). Sixty-five individuals of $M$. furnieri were measured (mm) (TL), weighted (g) (W), classified in juvenile or adult class following the guidelines 


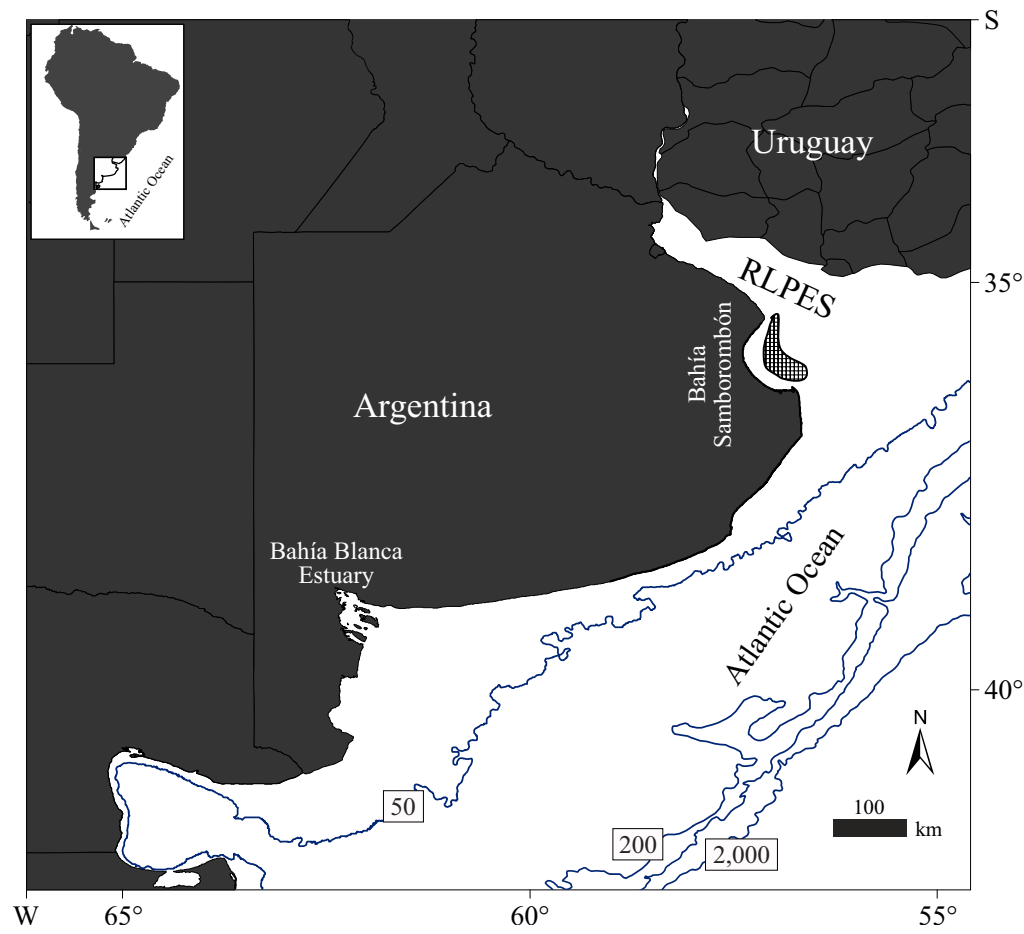

Figure 1. Location where commercial company caught white croaker (Micropogonias furnieri) in Río de la Plata Estuary System (RLPES) during 2017 (reticulate area).

set out by Vizziano et al. (2002), who determined the size at first maturity in $202 \pm 4.0 \mathrm{~mm}$ and 195 $\pm 0.4 \mathrm{~mm}$ for females and males, respectively. In addition, the Condition Factor (CF) was calculated according to $\mathrm{CF}=(\mathrm{W} \times 100) /(\mathrm{TL})^{3}($ da Costa and Araújo 2003).

Complete digestive tracts were removed and examined for PD ingestion analysis. Digestive tracts were dissolved and fully digested with a solution of hydrogen peroxide $\left(\mathrm{H}_{2} \mathrm{O}_{2}\right)$, adjusting the methodology used in several studies (Avio et al. 2015; Pazos et al. 2017; Arias et al. 2019). In order to reduce the time under chemical digestion ( $7 \mathrm{~d}$ for digestion with $30 \% \mathrm{H}_{2} \mathrm{O}_{2}$ for Arias et al. 2019), $48 \mathrm{~h}$ in $\mathrm{H}_{2} \mathrm{O}_{2} 60 \%$ solution was the optimal method used to obtain complete organic digestion. PD were identified and separated. Separation of long size fragments was made by the naked eye, while microplastics were identified by means of a magnifying glass and removed. PD obtained were counted, measured, and classified by type (sheet plastics, thread-like plastics, foamed synthetics, and hard fragments), color and size (microplastics: $<5 \mathrm{~mm}$, mesoplastics: 5$20 \mathrm{~mm}$ and macroplastics $>20 \mathrm{~mm}$; Barnes et al. 2009) according to the recommended standardization for the ingestion of marine debris from megafauna proposed by Provencher et al. (2017). The presence of PD was expressed as the frequency of occurrence (FO\%), defined as the proportion of individuals analyzed where PD was found. General Additive Models (GAM) were used to explore differences between total PD related to total length, weight, sex, and condition factor of fishes. Models were tested for goodness of fit and the most parsimonious model was chosen using the Akaiki's Information Criteria (AIC) (Burnham and Anderson 2003). Statistical analyses were performed using the free access program R (R Core Team 2021). 
Fish body lengths ranged from 229 to $759 \mathrm{~mm}$ (mean $397.5 \pm 146 \mathrm{~mm}$ ) and weight ranged between 235 and $632 \mathrm{~g}$ (mean $347.8 \pm 87 \mathrm{~g}$ ). The proportion of males was $57 \%$, while females represented $36 \%$ of samples, $7 \%$ of the specimens could not be identified; all fish sampled were adults.

Eighty percent of analyzed individuals ingested PD. A total of 186 items were counted, of which 156 were thread-like plastics $(\mathrm{FO}=83.9 \%)$ and 30 were fragments $(\mathrm{FO}=16.1 \%)$ (Figure 2). Average number of pieces of PD per digestive tract was $2.83 \pm 3.14$ ( $\max =17$ pieces $)$. The number of PD per digestive tract was not significantly affected by the total length, weight, sex, and condition factor of fishes (GAM model, $\left.\mathrm{R}^{2}=-0.0492 ; \mathrm{p}=0.62\right)$. Microplastic debris accounted for $85 \%$ of pieces found, most of which were $<2 \mathrm{~mm}(\mathrm{FO}=57.5 \%)$ (Figure 3$)$. There was no macroplastic presence in the guts analyzed.

Most prominent colors were blue (FO = $59.9 \%)$, followed by brown $(\mathrm{FO}=14 \%)$, black $(\mathrm{FO}=9.3 \%)$, red $(\mathrm{FO}=9.3 \%)$, violet $(\mathrm{FO}=2.3 \%)$, yellow $(\mathrm{FO}=2.3 \%)$, white $(\mathrm{FO}=1.7 \%)$, and green $(\mathrm{FO}=1.2 \%)$ (Figure 4$)$.

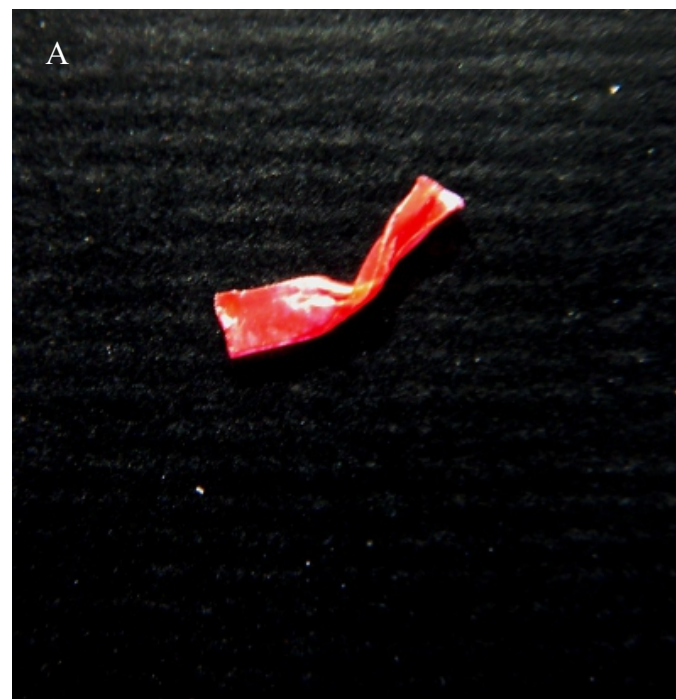

Our results demonstrate a high occurrence of meso and microplastics in $M$. furnieri from RLPES, where pieces $<2 \mathrm{~mm}$ and thread-like plastics were predominant. Microplastics comprised a very heterogeneous assemblage of particles that varied in size, shape, color, chemical composition and density (Galgani et al. 2015). Thread-like plastics dominated marine debris, including mainly fibers, which were also the predominant type of micro-debris in almost all studies of PD in fishes (e.g. Boerger et al. 2010; Lusher et al. 2013; Pazos et al. 2017; Arias et al. 2019).

PD found in $M$. furnieri had been previously reported only once in a different estuary area of Argentina (Bahía Blanca), located ca. $700 \mathrm{~km}$ southern away from our study area (Arias et al. 2019) (Figure 1). The number of pieces found per individual ( 12) in Arias et al. (2019) was greater than the values obtained in our paper, but the type of PD dominant in both was the same (thread-like plastics/fibres). White croaker is a benthic and generalist species (Carozza et al. 2004), previous reports have observed that benthic and demersal fish contained more fibres, while pelagic fish contained more fragments (Markic et al. 2018).
B

$5 \mathrm{~mm}$

Figure 2. Fragment (A) and thread-like (B) microplastics extracted from the guts of Micropogonias furnieri from Río de la Plata Estuary System (RLPES). 


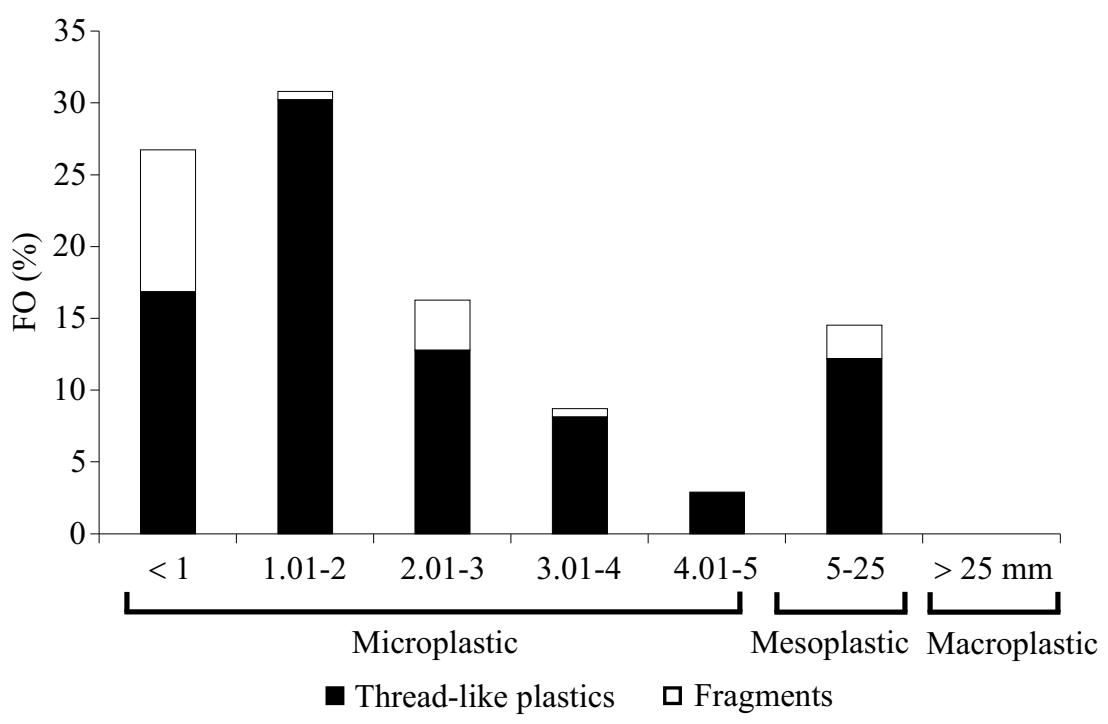

Figure 3. Frequency of occurrence $(\mathrm{FO} \%$ ) of plastic debris (PD) classified by size and type from the digestive tract of Micropogonias furnieri from Río de la Plata Estuary System (RLPES) in 2017.

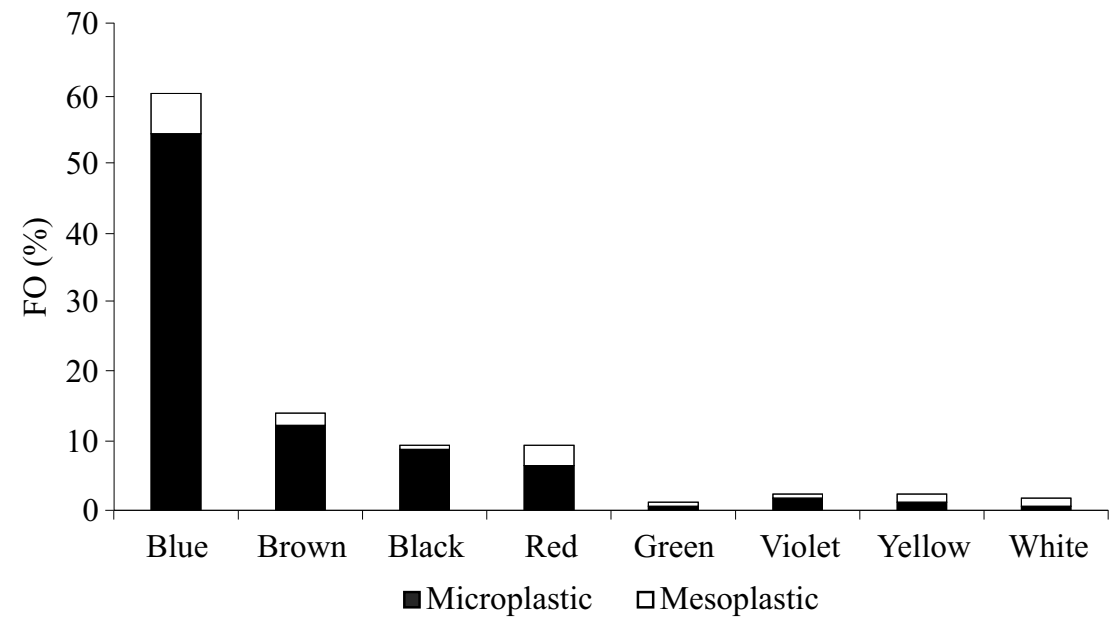

Figure 4. Frequency of occurrence (FO\%) of plastic debris (PD) classified by size and colors from the digestive tract of Micropogonias furnieri from Río de la Plata Estuary System (RLPES) in 2017.

Probably, this is a consequence that fibres are also commonly found as the prevalent type of PD in benthic sediments (Claessenes et al. 2011; Frias et al. 2016).

Differences obtained in the number of pieces per digestive tract in both studies could be related to several non-exclusive factors. Although PD biomagnification across a general marine food web is not supported by current field observations, it is not ruled out (Miller et al. 2020). There are differences in the feeding ecology between croakers from RLPES and from Bahía Blanca Estuary (Carozza et al. 2004) that could explain such differences. Besides that, the methodology used by Arias et al. (2019) was different from the one used in this paper. They used different con- 
centration and time of exposition of $\mathrm{H}_{2} \mathrm{O}_{2}$ to fully digest the digestive tract, and PD were inspected under a stereomicroscope, allowing the detection of plastic sizes not detected by our procedure. Despite the latter, our study represented a preliminary assessment and was focused on larger (mesoplastics and large microplastics) marine debris, and differences could be related to the low capability and equipment to detect the smallest range of microplastics.

In our study, blue color was remarkably more frequent than others. Blue PD, particularly microplastics, dominated microplastics found in many species, from freshwater fishes to marine megafauna (e.g. Ory et al. 2017; Meaza et al. 2020; Zantis et al. 2020); but for the same species Arias et al. (2019) observed that predominant colors were transparent and red. It was also observed that there was a difference in color distribution depending on locations (Markic et al. 2018), which could explain differences found between both areas.

Plastic ingestion causes physical and chemical effects on organisms (Kühn et al. 2015). Despite plastics are not bioaccumulated in individuals (Grigorakis et al. 2017), they can produce different chemical effects in individuals, such as changes in the body condition of the animals (Rochman et al. 2014; Luis et al. 2015). Several studies correlated the body condition of fish with plastic load but results were irresolute and opposite (Rummel et al. 2016; Cardozo et al. 2018; Compa et al. 2018). Our study, therefore, suggested that there was no evidence that total length, weight, sex, and condition factor were related with the PD presence in white croaker from RLPES, and probably that plastic ingestion occurred as a result of a certain individual trait (e.g. Toms et al. 2010).

Microplastics ingestion has been well documented for a range of commercially interested animals for human consumption in several countries, mainly in Europe and Asia (Barboza et al. 2018). Recently, the translocation of microplas- tics from the digestive tract to muscle tissue (Abbasi et al. 2018; Zitouni et al. 2020; Rasta et al. 2021) and the transfer of toxins from microplastics to tissue have been documented (Rochman et al. 2014). Even if the trophic transfer of microplastics in marine food webs remains unknown (Akhbarizadeh et al. 2019), physical and chemical studies of microplastics in marine commercial species of the region should continue as an essential topic in terms of public health and food security. At present, there are very few studies of microplastics in commercial species from Argentina (Pazos et al. 2017; Arias et al. 2019).

The presence of PD in the digestive tract of $M$. furnieri registered in this paper contributes to the evaluation of the overall impact of plastic pollution on the marine community of the region. Nonetheless, this work is a baseline study; future works could include chemical characterization of PD and new methodology for detection of smaller MPs.

\section{ACKNOWLEDGEMENTS}

We thank Santiago Barbini, who helped with age class classification of individuals, and Soledad Rosso from Área de Nutrición del Ecoparque in Buenos Aires who helped us arrange the samples. Also, we are incredibly grateful to the anonymous reviewer for improving the manuscript quality. JG and CDL were granted with Doctoral fellowships by Consejo Nacional de Investigaciones Científicas y Técnicas (CONICET).

\section{REFERENCES}

Abbasi S, Soltani N, Keshavarzi B, Moore F, Turner A, Hassanaghaei M. 2018. Microplastics in different tissues of fish and prawn from the Musa Estuary, Persian Gulf. Che- 
mosphere. 205: 80-87. doi:10.1016/j.chemos phere.2018.04.076

Acha EM, Mianzan HW, Iribarne O, GagliarDini DA, LASTA C, Daleo P. 2003. The role of the Rio de la Plata bottom salinity front in accumulating debris. Mar Pollut Bull. 46 (2): 197-202. doi:10.1016/S0025-326X(02)00356-9

Akhbarizadeh R, Moore F, Keshavarzi B. 2019. Investigating microplastics bioaccumulation and biomagnification in seafood from the Persian Gulf: a threat to human health? Food Addit Contam Part A. 36 (11): 16961708. doi:10.1080/19440049.2019.1649473

Arias AH, Ronda AC, Oliva AL, MarcovecCHIO JE. 2019. Evidence of microplastic ingestion by fish from the Bahía Blanca estuary in Argentina, South America. Bull Environ Contam Toxicol. 102 (6): 750-756. doi:10. 1007/s00128-019-02604-2

Avio CG, Gorbi S, Regoli F. 2015. Experimental development of a new protocol for extraction and characterization of microplastics in fish tissues: first observations in commercial species from Adriatic Sea. Mar Environ Res. 111: 18-26. doi:10.1016/j.marenvres.2015.06.014 Azevedo-Santos VM, Gonçalves GRL, Manoel PS, Andrade MC, Lima FP, Pelicice FM. 2019. Plastic ingestion by fish: a global assessment. Environ Pollut. 255: 112994. doi:10.1016/j.envpol.2019.112994

Baigún CRM, Colautti DC, Maiztegui $T$. 2016. Rio de la Plata (La Plata River) and Estuary (Argentina and Uruguay). In: FINLAYson C, Milton G, Prentice R, Davidson N, editors. The wetland book. Dordrecht: Springer. doi:10.1007/978-94-007-6173-5_243-1

Barboza L, VethaAK AD, Lavorante B, LunDebye AK, Guilhermino L. 2018. Marine microplastic debris: an emerging issue for food security, food safety and human health. Mar Pollut Bull. 133: 226-348. doi:10.1016/j. marpolbul.2018.05.047

Barnes DK, Galgani F, ThOMPSON RC, Barlaz M. 2009. Accumulation and fragmentation of plastic debris in global environments. Phil Trans R Soc B. 364 (1526): 1985-1998. doi:10.1098/rstb.2008.0205

Bessa F, Barría P, Neto JM, Frias JP, Otero V, Sobral P, MARQues JC. 2018. Occurrence of microplastics in commercial fish from a natural estuarine environment. Mar Pollut Bull. 128: 575-584. doi:10.1016/j.marpolbul.2018. 01.044

Boerger CM, Lattin GL, Moore SL, Moore CJ. 2010. Plastic ingestion by planktivorous fishes in the North Pacific Central Gyre. Mar Pollut Bull. 60 (12): 2275-2278. doi:10.1016/ j.marpolbul.2010.08.007

Burgues MF, Lenz J, Machín E, Genta L, TeiXeIRA De Mello F. 2020. Temporal variation of Kelp Gull's (Larus dominicanus) diet on a coastal island of the Rio de la Plata Estuary, Uruguay: refuse as an alternative food source. Waterbirds. 43: 65-74. doi:10.1675/063.043. 0107

Burnham K, Anderson DR. 2003. Model selection and multimodel inference: a practical information-theoretic approach. Springer Science \& Business Media.

Cardozo al, Farias EG, Rodrigues-Filho JL, Moteiro IB, Scandolo TM, Dantas DV. 2018. Feeding ecology and ingestion of plastic fragments by Priacanthus arenatus: what's the fisheries contribution to the problem? Mar Pollut Bull. 130: 19-27. doi:10.1016/j.marpolbul. 2018.03.010

Carozza C, Lasta C, Ruarte C, Cotrina C, Mianzan H, ACHa M. 2004. Corvina rubia (Micropogonias furnieri). In: SÁNCHEZ RP, BezzI SI, editors. El Mar Argentino y sus recursos pesqueros. Tomo 4. Los peces marinos de interés pesquero. Caracterización biológica y evaluación del estado de explotación. Mar del Plata: Instituto Nacional de Investigación y Desarrollo Pesquero (INIDEP). p. 255270.

Claessens M, De Meester S, Van Landuyt L, De Clerck K, Janssen CR. 2011. Occurrence 
and distribution of microplastics in marine sediments along the Belgian coast. Mar Pollut Bull. 62 (10): 2199-2204. doi:10.1016/j. marpolbul.2011.06.030

Compa M, Ventero A, Iglesias M, Deudero S. 2018. Ingestion of microplastics and natural fibres in Sardina pilchardus (Walbaum, 1792) and Engraulis encrasicolus (Linnaeus, 1758) along the Spanish Mediterranean coast. Mar Pollut Bull. 128: 89-96. doi:10.1016/j. marpolbul.2018.01.009

Da Costa MR, Araúso FG. 2003. Length-weight relationship and condition factor of Micropogonias furnieri (Desmarest) (Perciformes, Sciaenidae) in the Sepetiba Bay, Rio de Janeiro State, Brazil. Rev Bras Zool. 20 (4): 685690.

Denuncio P, Bastida R, Dassis M, Giardino G, Gerpe M, Rodríguez D. 2011. Plastic ingestion in Franciscana dolphins, Pontoporia blainvillei (Gervais and d'Orbigny 1844), from Argentina. Mar Pollut Bull. 62 (8): 18361841. doi:10.1016/j.marpolbul.2011.05.003

Denuncio P, Mandiola MA, Pérez Salles SB, Machado R, Ott PH, De Oliveira LR, RODRIGUEZ D. 2017. Marine debris ingestion by the South American fur seal from the Southwest Atlantic Ocean. Mar Pollut Bull. 122 (1-2): 420-425. doi:0.1016/j.marpolbul. 2017.07.013

DERRAIK JG. 2002. The pollution of the marine environment by plastic debris: a review. Mar Pollut Bull. 44 (9): 842-852. doi:10.1016/ S0025-326X(02)00220-5

Devriese Li, Van der Meulen MD, Maes T, Bekaert K, Paul-Pont I, Frère L, Robbens J, VethaAK AD. 2015. Microplastic contamination in brown shrimp (Crangon crangon, Linnaeus 1758) from coastal waters of the Southern North Sea and Channel area. Mar Pollut Bull. 98 (1-2): 179-187. doi:10.1016/j. marpolbul.2015.06.051

ERIKSEN M, Lebreton LCM, CARSON HS, ThiEL M, Moore CJ, Borerro JC, Galgani F, Ryan
PG, REISSER J. 2014. Plastic pollution in the world's oceans: more than 5 trillion plastic pieces weighing over 250,000 tons afloat at sea. PLoS ONE. 1-15. doi:10.1371/journal. pone. 0111913

Foekema EM, De Gruijter C, Mergia MT, van Franeker JA, Murk AJ, Koelmans AA. 2013. Plastic in north sea fish. Environ Sci Technol. 47 (15): 8818-8824. doi:10.1021/es 400931b

Franco-Trecu V, Drago M, Katz H, Machín E, MARín Y. 2017. With the noose around the neck: marine debris entangling otariid species. Environ Pollut. 220: 985-989. doi:10.1016/j. envpol.2016.11.057

Frere L, Paul-Pont I, Rinnert E, Petton S, JafFré J, Bihannic I, Soudant P, Lambert C, Huvet A. 2017. Influence of environmental and anthropogenic factors on the composition, concentration and spatial distribution of microplastics: a case study of the Bay of Brest (Brittany, France). Environ Pollut. 225: 211222. doi:10.1016/j.envpol.2017.03.023

Frias JPGL, Gago J, Otero V, Sobral P. 2016. Microplastics in coastal sediments from Southern Portuguese shelf waters. Mar Environ Res. 114: 24-30. doi:10.1016/j.marenvres. 2015.12.006

Galgani F, Hanke G, Maes T. 2015. Global distribution, composition and abundance of marine litter. In: Bergmann M, Gutow L, Klages M, editors. Marine anthropogenic litter. Cham: Springer. p. 29-56. https://doi.org/10.1007/ 978-3-319-16510-3 2

Gall SC, ThOMpson RC. 2015. The impact of debris on marine life. Mar Pollut Bull. 92 (12): 170-179. doi:10.1016/j.marpolbul.2014. 12.041

Gonzalez Carman V, Acha EM, Maxwell SM, Albareda D, Campagna C, Mianzan $\mathrm{H}$. 2014. Young green turtles, Chelonia mydas, exposed to plastic in a frontal area of the SW Atlantic. Mar Pollut Bull. 78 (1-2): 56-62. doi:10.1016/j.marpolbul.2013.11.012 
GREGORY MR. 2009. Environmental implications of plastic debris in marine settings-entanglement, ingestion, smothering, hangers-on, hitch-hiking and alien invasions. Phil Trans $\mathrm{R}$ Soc B. 364 (1526): 2013-2025. doi:10.1098/ rstb.2008.0265

Grigorakis S, Mason SA, Drouillard KG. 2017. Determination of the gut retention of plastic microbeads and microfibers in goldfish (Carassius auratus). Chemosphere. 169: 233238. doi:10.1016/j.chemosphere.2016.11.055

JAMBECK JR, Geyer R, Wilcox C, Siegler TR, Perryman M, Andrady A, Narayan R, LaW KL. 2015. Plastic waste inputs from land into the ocean. Science. 347: 768-771. doi:10.1126/ science. 1260352

JEPSEN EM, DE BRUYN PN. 2019. Pinniped entanglement in oceanic plastic pollution: a global review. Mar Pollut Bull. 145: 295-305. doi:10.1016/j.marpolbul.2019.05.042

KÜHN S, Rebolledo ELB, van FraneKer JA. 2015. Deleterious effects of litter on marine life. In: Bergmann, M, Gutow L, Klages M, editors. Marine anthropogenic litter. Cham: Springer. p. 75-116. doi:10.1007/978-3-31916510-3_4

KÜHN S, van FraneKer JA. 2020. Quantitative overview of marine debris ingested by marine megafauna. Mar Pollut Bull. 151: 110858. doi:10.1016/j.marpolbul.2019.110858

LAIST DW. 1997. Impacts of marine debris: entanglement of marine life in marine debris including a comprehensive list of species with entanglement and ingestion records. In: COE JM, Rogers DB, editors. Marine debris. New York: Springer Series on Environmental Management. p. 99-139. doi:10.1007/978-14613-8486-1 10

Lenzi J, Burgues MA, Carrizo D, Machín E, Teixeira-de Mello F. 2016. Plastic ingestion by a generalist seabird on the coast of Uruguay. Mar Pollut Bull. 107: 71-76. doi:10.1016/j. marpolbul.2016.04.016

Liboiron M, Liboiron F, Wells E, RichÁRd N,
Zahara A, Mather C, Bradshaw H, Murichi J. 2016. Low plastic ingestion rate in Atlantic cod (Gadus morhua) from Newfoundland destined for human consumption collected through citizen science methods. Mar Pollut Bull. 113: 428-437. doi:10.1016/j.marpolbul. 2016.10.043

Luís LG, Ferreira P, Fonte E, Oliveira M, GuiLHERMINO L. 2015. Does the presence of microplastics influence the acute toxicity of chromium (VI) to early juveniles of the common goby (Pomatoschistus microps)? A study with juveniles from two wild estuarine populations. Aquat Toxicol. 164: 163-174. doi:10. 1016/j.aquatox.2015.04.018

Lusher AL, Mchugh M, ThOMpson RC. 2013. Occurrence of microplastics in the gastrointestinal tract of pelagic and demersal fish from the English Channel. Mar Pollut Bull. 67 (12): 94-99. doi:10.1016/j.marpolbul.2012.11. 028

Machovsky-Capuska Ge, Amiot C, Denuncio P, Grainger R, Raubenheimer D. 2019. A nutritional perspective on plastic ingestion in wildlife. Sci Total Environ. 656: 789-796.

[MAGyP] Ministerio DE Agricultura GanadeRÍA Y PESCA. 2021. [updated 2020 Mar 8; acceded 2021 March 21]. https://www.argentina. gob.ar/agricultura.

Markic A, Niemand C, Bridson JH, MazouniGaertner N, Gaertner JC, Eriksen M, Bowen M. 2018. Double trouble in the South Pacific subtropical gyre: increased plastic ingestion by fish in the oceanic accumulation zone. Mar Pollut Bull. 136: 547-564. doi:10.1016/j.marpolbul.2018.09.031

Meaza I, Toyoda J, Wise JP. 2020. Microplastics in Sea Turtles, marine mammals and humans: a one environmental health perspective. Front Environ Sci. 8: 298.

Mianzan H, Lasta C, Acha E, Guerrero R, Macchi G, Bremec C. 2001. The Rio de la Plata estuary, Argentina-Uruguay. In: SeELIGER U, KJERFVE B, editors. Coastal marine 
ecosystems of Latin America. Ecological studies (analysis and synthesis). Vol. 144. Berlin, Heidelberg: Springer. p. 185-204.

Miller ME, Hamann M, Kroon FJ. 2020. Bioaccumulation and biomagnification of microplastics in marine organisms: A review and meta-analysis of current data. PLoS ONE. 15 (10): e0240792. doi:10.1371/journal.pone. 0240792

Neves D, Sobral P, Ferreira JL, Pereira T. 2015. Ingestion of microplastics by commercial fish off the Portuguese coast. Mar Pollut Bull. 101 (1): 119-126. doi:10.1016/j.marpolbul. 2015.11.008

Ory N, Chagnon C, Felix F, Fernández C, Ferreira JL, Gallardo C, Garcés Ordoñez O, Henostroza A, Laaz E, Mizraji R, et al. 2018. Low prevalence of microplastic contamination in planktivorous fish species from the southeast Pacific Ocean. Mar Pollut Bull. 127: 211-216. doi:10.1016/j.marpolbul.2017. 12.016

Ory NC, Sobral P, Ferreira JL, Thiel M. 2017. Amberstripe scad Decapterus muroadsi (Carangidae) fish ingest blue microplastics resembling their copepod prey along the coast of Rapa Nui (Easter Island) in the South Pacific subtropical gyre. Sci Total Environ. 586: 430-437. doi:10.1016/j.scitotenv.2017.01.175

Pazos RS, Maiztegui T, Colautti DC, ParaCAMPO AH, GÓMEZ N. 2017. Microplastics in gut contents of coastal freshwater fish from Río de la Plata estuary. Mar Pollut Bull. 122 (1-2): 85-90. doi:10.1016/j.marpolbul.2017. 06.007

Provencher JF, Bond AL, Avery-Gomm S, BorRelle SB, Rebolledo ElB, Hammer S, KÜHN S, LaVers JL, Mallory ML, Trevail A, et al. 2017. Quantifying ingested debris in marine megafauna: a review and recommendations for standardization. Anal Methods. 9 (9): 1454-1469. doi:10.1039/C6AY02419J

R Core Team. 2021. R: A language and environment for statistical computing. R Foundation for Statistical Computing. Version 4.0.4. Vienna. http://www.R-project.org/.

Rasta M, Sattari M, Taleshi MS, Namin JI. 2021. Microplastics in different tissues of some commercially important fish species from Anzali Wetland in the Southwest Caspian Sea, Northern Iran. Mar Pollut Bull. 169: 112479. doi:10.1016/j.marpolbul.2021.112479

RochMAN CM. 2015. The complex mixture, fate and toxicity of chemicals associated with plastic debris in the marine environment. In: BERGMANn M, Gutow L, KLAGes M. editors. Marine anthropogenic litter. Cham: Springer. p. 117-140. doi:10.1007/978-3-319-16510-3_5

Rochman CM, Kurobe T, Flores I, Teh SJ. 2014. Early warning signs of endocrine disruption in adult fish from the ingestion of polyethylene with and without sorbed chemical pollutants from the marine environment. Sci Total Environ. 493: 656-661. doi:10.1016/ j.scitotenv.2014.06.051

Rummel CD, LÖDER MG, FRICKe NF, LANG T, Griebeler EM, Janke M, Gerdts G. 2016. Plastic ingestion by pelagic and demersal fish from the North Sea and Baltic Sea. Mar Pollut Bull. 102 (1): 134-141. doi:10.1016/j.marpolbul. 2015.11.043

Santos RG, Andrades R, Demetrio GR, Kuwai GM, Sobral MF, dE Souza Vieira J, MACHOVSKY-CAPUSKA G.E. 2020. Exploring plastic-induced satiety in foraging green turtles. Environ Pollut. 265: 114918. doi:10.1016/ j.envpol.2020.114918

Toms CN, ECHEVARria DJ, JouANDOT DJ. 2010. A methodological review of personality-related studies in fish: focus on the shy-bold axis of behavior. Int J Com Psychol. 23 (1): 1-25. doi:10.5070/P4231020275

Van Caumenberghe L, Janssen CR. 2014. Microplastics in bivalves cultured for human consumption. Environ Pollut. 193: 65-70. doi:10.1016/j.envpol.2014.06.010

Vizziano D, Forni F, SAONA G, Norbis W. 2002. Reproduction of Micropogonias funieri in a 
shallow temperate coastal lagoon in the southern Atlantic. J Fish Biol. 61: 196-206. doi:10.1111/j.1095-8649.2002.tb01771.x

Zantis L, Carroll EL, Nelms SE, Bosker T. 2020. Marine mammals and microplastics: a systematic review and call for standardisation. Environ Pollut. 269: 116142. doi:10.1016/j. envpol.2020.116142
Zitouni N, Bousserrhine N, Belbekhouche S, Missawi O, Alphonse V, Boughatass I, BANNI M. 2020. First report on the presence of small microplastics $(\leq 3 \mu \mathrm{m})$ in tissue of the commercial fish Serranus scriba (Linnaeus. 1758) from Tunisian coasts and associated cellular alterations. Environ Pollut. 263: 114576. doi:10.1016/j.envpol.2020.114576 
